\title{
Protective effect of licorice (glycyrrhiza glabra linn) on indomethacin-induced gastric ulcer in male albino rats.
}

\author{
Aml Hashem ${ }^{1}$, Rabab Esawy, Nabil Taha ${ }^{2}$, and Mohamed Lebda ${ }^{3}$ \\ ${ }^{1,2,3}$ Biochemistry Department, Faculty of veterinary medicine, Alexandria University, Egypt
}

\begin{tabular}{|c|c|}
\hline A R T I CLE I NFO & A B S T R A C T \\
\hline $\begin{array}{l}\text { Keywords: } \\
\text { Glycyrrhiza glabra Linn, inflammation, } \\
\text { Peptic ulcer, Interleukin } 6 .\end{array}$ & $\begin{array}{l}\text { Objective: This study aimed to investigate the protective role of } \\
\text { licorice on indomethacin-induced gastric ulcer in male albino rats } \\
\text { compared to anti-ulcer drug; ranitidine. Methods: Fifty male adult }\end{array}$ \\
\hline Abbreviations & rats were randomly allocated into five groups (10 rats/each); control, \\
\hline & $\begin{array}{l}\text { licorice, indomethacin, licorice/indomethacin, and } \\
\text { ranitidine/indomethacin treated groups. Serum, gastric juice, and } \\
\text { gastric tissues were collected for biochemical and histopathological } \\
\text { analysis. Results: The obtained results revealed that licorice pre- } \\
\text { treatment showed potent anti-ulcerative effect as; volume and total } \\
\text { acidity of gastric secretion were markedly decreased, attenuated the } \\
\text { severity of gastric lesion as confirmed by PM and histopathological } \\
\text { examination showed preservation of gastric epithelium and ulcer } \\
\text { healing. Moreover, gastric ulcer score, gastric MDA, and serum IL-6 } \\
\text { were obviously decreased along with increased gastric GSH, CAT } \\
\text { activity and NO. Interestingly licorice had no side effects on the liver } \\
\text { and kidney evidenced by increased serum total protein, and albumin } \\
\text { besides declined the activities of serum aminotransferases without } \\
\text { significant changes in the serum urea, uric acid, sodium, potassium, } \\
\text { and chloride levels. Conclusion: It was concluded that the used dose } \\
\text { of licorice showed potent anti-ulcerative activity and more safer on } \\
\text { the liver and kidney functions compared to the standard commercial } \\
\text { drug; ranitidine. }\end{array}$ \\
\hline
\end{tabular}

\section{Introduction:}

Peptic ulcer is one of the most common gastrointestinal disease [1].It occurs due to the imbalance between the aggressive gastric acid secretion and defensive gastric mucosal integrity factors affecting considerable number of people worldwide [2]. Ulcer is an erosion of mucosal layer or excavation of the tissue surface due to sloughing of inflammatory necrotic tissue. Negative outcomes include bleeding, perforation, and even death may occur [3]. Ulcer treatment aimed to relieve pain, crucial, and prevent its' reoccurrence; but appropriate treatment regimen has not been found, efforts are still on to find suitable treatments for ulcer [4]. Group of endogenous and exogenous factors including acid, pepsin, stress, and noxious agents as alcohol, non-steroidal antiinflammatory drugs (NSAIDs), Helicobacter pylori, smoking, and alcohol consumption known to cause or aggravate gastric ulcer [5]. Studies have shown that more than $50 \%$ of patients taking indomethacin have adverse reactions include discomfort, ulcers, and bleeding [6]. It has been shown to increase both lipid peroxidation and the production of 
reactive oxygen species (ROS) in the gastrointestinal mucosa of laboratory animals [7], that can damage membranes and stomach tissues [8].

Using of herbal medicines for prevention and treatment of different pathologies is in continuous expansion worldwide. Several plants and herbs have been used to treat GI disorders, including gastric ulcer [9] as Aloe vera, Chilli pepper, Ginseng, and Ginger. Licorice (Glycyrrhiza glabra Linn) is a plant used in traditional medicine for its ethno-pharmacological value. It is found to contain important phytoconstituents as glycyrrhizin, glycyrrhizinic acid, glabrin $\mathrm{A}$ and $\mathrm{B}$, and isoflavones. It is effectively used as anti-inflammatory, anti-bacterial, anti-fungal, anti-diabetic, antiviral, anti-ulcer, antioxidant, and antidiuretic agent [10]. Licorice is usually used to improve health, lengthen life span [11], enhance memory activity [12], and heart condition [13]. Licorice root was the most effective in reducing body weight and overall fat deposition [14]. It is also traditionally used in the treatment of ulcer and tumor [15]. Deglycyrrhized licorice (DGL) is used in peptic ulcers due to its flavonoids. This form has a reduced mineralocorticoid activity and therefore used in treatment of peptic ulcer for healing purposes[16].

The current study aimed to clear the protective role of $100 \mathrm{mg} / \mathrm{kg}$ licorice on peptic ulcer induced by indomethacin in male rats, its potency and safety compared to ranitidine through estimation of some selected biochemical and histopathological indices.

\section{Materials and Methods: Chemicals and Reagents}

Licorice capsule $450 \mathrm{mg}$ was purchased from (Nature's Way Brands,
Green Bay, WI54311. USA). Indomethacin capsule $25 \mathrm{mg}$ (KAHIRA. Pharm \& CHEM. IND. CO. Egypt), Ranitidine tablet $150 \mathrm{mg}$ (Med. Union Pharm, Egypt), Kits for Urea, Uric acid, AST, ALT was purchased from Vitro Scient. Kits for Albumin, Total protein was purchased from Bio-mid Diagnostic, Egypt. Kits for $\mathrm{Na}, \mathrm{K}, \mathrm{Cl}$, IL-6 supplied by Cobas. Kits for NO, GSH, CAT, MDA was purchased from Biodiagnostic Co, Egypt.

\section{Experimental Design}

Fifty adult white male albino rats weighting $150 \pm 20 \mathrm{~g}$ were obtained from Medical Technology center, Medical Research Institute (MRI), Alexandria University. Rats were housed in separate cages. Fresh and clean drinking water were supplied free access, were maintained on balanced diet, under 12/12 h light/dark cycle throughout the period of experiment, were left two weeks for acclimatization. All animal treatments completely strictly with institutional ethical guidelines of the care and use of laboratory animals and minimizing stressful external condition affect the laboratory animals as much as possible.

Rats were randomly divided in to 5 groups each 10 rats. Group I received diet without any treatment served as control. Group II received licorice orally $(100 \mathrm{mg} / \mathrm{kg})$ daily for 3 weeks. Group III received indomethacin (40 $\mathrm{mg} / \mathrm{kg}$ ) oral single dose by gastric gavage [17]. Group IV received licorice $(100 \mathrm{mg} / \mathrm{kg})$ for 3 weeks, followed by single dose of indomethacin $(40 \mathrm{mg} / \mathrm{kg})$. Group V received ranitidine $50 \mathrm{mg} / \mathrm{kg}$ (reference drug) orally for 3 weeks [18] followed by single dose of indomethacin $(40 \mathrm{mg} / \mathrm{kg})$. All rats 
treated with indomethacin were sacrificed after $4 \mathrm{~h}$ [19].

\section{Blood collection}

At the end of experiment, rats after overnight fasting were anesthetized. Blood samples were collected from retro-orbital sinus of eye in dry, clean tubes, were allowed to clot. Serum was separated by centrifugation at $3000 \mathrm{rpm}$ for $15 \mathrm{~min}$, transferred to Eppendorf, frozen at 20- 0c for biochemical analysis.

\section{Collection of gastric juice}

The anterior abdominal wall was opened and the stomach was dissected. After dissection, rats' stomachs were ligated from its two ends (the pylorus and the lower esophagus), then injected with $2 \mathrm{ml}$ distilled water. A small incision was made for each fore stomach, and the stomach contents were expelled [20]. Gastric contents were collected in tubes measured for volume. Gastric juice was centrifuged at $4000 \mathrm{rpm}$ for $15 \mathrm{~min}$ and the supernatant was used for determining $\mathrm{pH}$ and total acidity [21].

\section{Preparation of gastric homogenate}

Stomach was taken after rats had been sacrificed, specimen were immediately removed, washed several times with cold normal saline, blotted between two damp filter papers, weighed $0.5 \mathrm{~g}$, and stored at freezer. Specimen was transferred to a Petri dish containing cold normal saline and a container with ice for preparation of stomach homogenate. Gastric tissues were homogenized, centrifuged at $4000 \mathrm{rpm}$ for $15 \mathrm{~min}$ at $4^{\circ} \mathrm{C}$ then the supernatants were utilized.

\section{Biochemical analysis}

Gastric juice collected, examined for volume, $\mathrm{pH}$, and Total acidity according to [22]. The surface area (A) $\mathrm{cm} 2$ covered by each lesion was measured [23]. Ulcer index and Ulcer inhibition \% calculated according to [24]. Serum analyzed for IL-6 according to [25], total protein according to [26], albumin according to [27], ALT, AST activity was determined according to the kinetic method described by [28], urea and uric acid was determined according to [29]. Sodium was determined according to [30], potassium was determined according to [31], chloride was determined according to [32]. Gastric tissue homogenate analyzed for CAT according to [33], GSH was determined according to [34], NO was determined according to [35].

\section{Histophathological analysis}

$0.5 \mathrm{~g}$ stomach were collected, washed by cold normal saline solution, dried by double sheet filter paper, fixed in $10 \%$ neutral buffered formalin $(\mathrm{pH}=7.0)$ for $24 \mathrm{~h}$, transferred in to $70 \%$ ethyl alcohol. Samples were cleared in xylol for $6 \mathrm{~h}$, placed in a crucible containing soft paraffin, kept in an oven at $56^{\circ} \mathrm{C}$ for $12 \mathrm{~h}$. Samples were blocked in hard paraffin, cut into sections of 5 microns thickness, cleared in xylene, impregnated in paraffin wax, 5-7 $\mu \mathrm{m}$ sections were taken, stained with Harri's hematoxylin \& eosin according to [36].

\section{Statistical analysis}

All analyses were performed using SPSS statistical software package (version 22.0 SPSS Inc., Chicago, USA). Quantitative variables were first tested for normality of data and homogeneity of variances. One-way analysis of variance (ANOVA) followed by Duncan's multiple range test was carried out to detect group differences. Ulcer score as well as data invalidated assumption for ANOVA were assessed with the non-parametric 
alternatives (Kruskal-Wallis test then Mann-Whitney U test as a post hoc). Differences were considered statistically significant at $\mathrm{P}<0.05$. Ulcer score was expressed as median and range, and other variables as mean and standard error of mean.

\section{Results and disscussion:}

Data in table (1), (2), and (3) showed that IND caused significant increase in volume, total acidity, and marked decreased $\mathrm{pH}$ of gastric secretion at $(\mathrm{P}$ $\leq 0.05)$. IND also induced marked increase in ulcer index, ulcer score, and IL-6. In addition, IND caused obvious decreased gastric levels of GSH, NO, and CAT activity and increased gastric MDA as compared to control. This came in harmony with [37] who mentioned that IND caused alterations in gastric secretions of rats. This may be due to histamine over secretion contributes to increased volume of gastric juice [38], and low prostaglandin level that impairs almost all aspects of gastro-protection and increases acid secretions that increase the total acidity [39]. Low $\mathrm{pH}$ is a manifestation of high $\mathrm{H}+$ concentration in gastric juice that act as a risk factor for gastric damage and ulcer [40]. The ulcer also may be caused by direct oxidative action [41], lipid peroxidation, or high gastric volume and total acidity that explained by high ulcer score, index, and IL-6. IND facilitate lipid peroxidation, and over production of free radicals that thwart antioxidant enzymes activities [42] that indicated by low levels of gastric GSH, NO, and CAT activity and high gastric MDA. This indicated by PM and histopathological analysis that showed marked mucosal lesions, long hemorrhagic bands, petechial lesions with ulcerative inflammation, sever distraction of surface epithelium mucosa and sloughing, sever destructive muscularis mucosa, and numerous hemorrhaged blood vessels.

However, licorice pretreatment or ranitidine produced pronounced decrease in volume, total acidity and increased $\mathrm{pH}$, reduced areas and severity of gastric lesions in the term of ulcer score, index, and levels of IL-6 at $(\mathrm{P} \leq 0.05)$ compared to IND-treated rats. Also, produced significant increased levels of GSH, NO, and CAT activity and decreased MDA. Licorice can reduce gastric volume and total acidity, produce thick protective mucus for stomach lining which protect against inflammations, gastritis and peptic ulcerations [43]. Licorice can increase the quantity and viscosity of mucus, enhancing the mucosal barrier. Antiulcer activity of licorice due to the inhibitory effect of glycoside glycyrrhizin on releasing PGE2, and ROS generation causing gastric ulcer [44] [45]. Licorice has antioxidant and anti-inflammatory properties that reduce oxidative damage. The level of IL-6 decreased by treatment with GA and LQ, while the IL-6 level inhibited by LG [46]. Licorice components inhibit the generation of various mediators as MDA produced by activated macrophages, and increased the antioxidant levels of GSH and CAT activity, due to flavonoids and tannins component [47]. Ulcer inhibition \% of ranitidine pre-treated groups $(46.7 \%)$ more than licorice pre-treated groups $(45.1 \%)$. while, licorice pretreatment produced significant increased NO, and CAT and decreased MDA level compared to ranitidine treated rats. This indicated by PM and histopathological analysis that showed very mild mucosal lesions, preservation of normal tubular arrangement of gastric glands, and minor changes in the structure of gastric glands. 
Result in table (4), and (5) cleared that IND had significant decrease on total protein, albumin, and globulin and marked increase on ALT and A/G ratio at $(\mathrm{P} \leq 0.05)$ as compared to control. This may be due to hepatic degenerative changes, cell necrosis surrounding central veins, glycogen depletion [48] [49], periportal hepatic necrosis, kupffer cell proliferation, and hepatotoxicity [50] [51]. While licorice pretreatment produced marked increased total protein, albumin, and globulin and marked decrease on ALT and $A / G$ ratio as compared to IND treated rats. Licorice pretreatment produced significant increase on Total protein and decreased ALT compared to ranitidine pre-treated groups. Glycyrrhizin reduced liver enzymes in rats and induced interferon production in patients with chronic hepatitis B and $C$ [52] [53]. The antioxidant and free radical scavenging activities of licorice have been assessed to exert antihepatotoxic effects related to strong antioxidant activity [54] [55].

Data in table (6) and (7) indicated that IND had obvious increase on uric acid. This may be due to increase uric acid over production, or decrease of excretion [56]. This agree with [57] [58] as IND lead to renal structural and functional damage and renal oxidative damage. Licorice used by [59] in hepatotoxic rats and by [60] in alloxandiabetic rats and indicated that licorice may be useful in patients with renal insufficiency. No significant difference between treated groups on sodium, potassium and chloride. In this study licorice had no effect may be due to the used dose or duration.

\section{Conclussion}

It was concluded that licorice showed great antioxidant and free radical scavenging activities used to protect from tissues damage and gastric ulcer. Licorice shown to be more effective and safer than ranitidine in ulcer treatment.

\section{References:}

1. Dandiya, P.C., and Kulkarni, S.K. (2005). Introduction to Pharmacology. Vallabh Prakashan. New Delhi, 247.

2. Ateufack, G., Mokam, E., Mbiantcha, M., et al. (2015). Gastroprotective and ulcer healing effects of piptadeniastrum Africanum on experimentally induced gastric ulcers in rats. BMC Complementary and Alternative Med; 15: 1 - 10.

3. Yuan, Y., Padol, T.I., and Hunt R.H. (2006). Peptic ulcer disease today. Nat. Clin. Pract Gastroenterol \& Hepatol, 3 (2).

4. Ibrahim, A.A., Abdulqader, A.A., Jaber, S.M., Mohammed, A.A., Mohammed, O.A., Syed, R. and Shaffi, S. (2008). Gastroprotective effect of an aqueous suspension of black cumin Nigella sativa on Necrotizing Agents-induced Gastric injury in Experimental animals. Saudi J Gastroenterol, 14(3): 128-134.

5. Syam, A.F, Sadikin, M., Wanandi, S.I. and Rani, A.A. (2009). Molecular mechanism on healing process of peptic ulcer. Acta Med Indones, 41: 95-98.

6. Odabasoglu, F., Halici, Z., Cakir, A., et al. (2008). Beneficial effects of vegetable oils (corn, olive and sunflower 
oils) and $\alpha$-tocopherol on antiinflammatory and gastrointestinal profiles of indomethacin in rats. Europ J. of Pharmacol; 591: 300-306.

7. Mota, K., Dias, G., Pinto, M., Luiz-Ferreira, A., SouzaBrito, A., Hiruma-Lima, C., Barbosa-Filho, J., and Batista, L., (2009). Flavonoids with gastroprotective activity. Molecules, 14, 979-1012.

8. Monica Damle (2014). Glycyrrhiza glabra (Liquorice) - a potent medicinal herb, Int. J. of Herb. Med., 2(2): 132-136.

9. Tang, Z.; Li, T.; Tong, Y.; et al. (2015). A Systematic Review of the Anticancer Properties of Compounds Isolated from Licorice (Gancao). Planta. Med.; 81: 1670-1687.

10. Zhang, Q. and Ye, M. (2009). Chemical analysis of the Chinese herbal medicine GanCao (licorice). J. Chromatogr; 13: 1954-1969.

11. Marsovna, A.; Kedelevna, $Z$. and Petrovna, P. (2015). The Development Technologies of Double Layer Suppositories on the Basis of Licorice Extract and Paracetamol. J. of Pharm and Pharmacol; 3: 531-537.

12. Hajirahimkhan, A.; Simmler, C.; Yuan, Y.; et al. (2013). Evaluation of estrogenic activity of licorice species in comparison with hops used in botanicals for menopausal symptoms. PLoS One; 8: 1 11.
13. Khare, C.P. (2004). Encyclopedia of Indian Medicinal Plants. New York: Springer-Verlag; 233-235.

14. Kokate, C.K., Purohit, A.P, Gokhale, S.B. (2009). Pharmacognosy, 43rd edition. 8.52-6.

15. Sofidiya, M.; Agufobi, L.; Akindele, A.; et al. (2012). Effect of Flabellaria paniculata Cav. extracts on gastric ulcer in rats. BMC Complementary and Alternative Med; 12 - 16.

16. Soliman NA, Zineldeen DH, Katary MA, Ali DA (2016). $\mathrm{N}$-acetylcysteine a possible protector against indomethacininduced peptic ulcer: crosstalk between antioxidant, antiinflammatory, and antiapoptotic mechanisms. Can J Physiol Pharmacol 14: 1-8.

17. Huo, H.; Wang, B.; Liang, Y.; et al. (2011). Hepatoprotective and Antioxidant Effects of Licorice Extract against CCl4Induced Oxidative Damage in Rats. Int. J. Mol. Sci.; 12: 6529-6543.

18. Hsu, D., Chu, P., Chandrasekaran, V.R., and Liu, M., (2009). Sesame Lignan sesamol protects against aspirin-induced gastric mucosal damage in rats. J. of Functional Foods. (1): 335 -349.

19. Hawk, P.B., Oser, B.L. and Summerson, H.W., (1947). Practical physiological chemistry. 12th ed. London, Churchill, P. 347, 1947. 
20. Parmar, N., and Desai, J., (1993). A review of the current methodology for the evaluation of gastric and duodenal antiulcer agents. Indian J. Pharmacol., 25: 120-135.

21. Murakami, S.; Arai, I.; Muramatsu, M.; Otomo, S.; Baba, K.; Kido, T.; Kozawa, M., (1992). Inhibition of gastric $\mathrm{H}+, \mathrm{K}+-$ ATPase and acid secretion by cassigarol $\mathrm{A}$, a polyphenols from Cassia garrettianaCraib. Biochem. Pharmacol, 44: 33-37.

22. Murakami, S.; Arai, I.; Muramatsu, M.; Otomo, S.; Baba, K.; Kido, T.; Kozawa, M., (1992). Inhibition of gastric $\mathrm{H}+\mathrm{K}+-$ ATPase and acid secretion by cassigarol $\mathrm{A}$, a polyphenols from Cassia garrettianaCraib. Biochemical Pharmacology, 44: 33-37.

23. Chan, D.W., and Perlstein, N.T., (1987). Immunoassay: A Practical Guide, Eds, Academic Press: New York, p71.

24. Burtis, C.A., Ashwood, E.R., and Bruns, D.E., (2012). Tietz Textbook of Clinical Chemistry and Molecular diagnostics 5th edition. Indian J Clin Biochem. 28(1): 104-105.

25. Doumas, B.T.; Watson, W. A., and Biggs, H.G., (1971). Albumin standards and the measurement of serum albumin with bromcresol green. Clin Chim Acta.; 31:87-96.

26. Bergmeyer, H.U.; Hørder, M., and Rej. R., (1986). International Federation of
Clinical Chemistry (IFCC) Scientific Committee, Analytical Section: approved recommendation (1985) on IFCC methods for the measurement of catalytic concentration of enzymes. Part 3. IFCC method for alanine aminotransferase (L-alanine: 2oxoglutarate aminotransferase, EC 2.6.1.2). J Clin Chem Clin Biochem.; 24: 481- 495.

27. Rock, R.C. Walker, W.G. and Jennings, C.D., (1987). Nitrogen metabolites and renal function. In: Tietz NW. Fundementals of clinical chemistry 3rd Ed: 669-704. Philadelphia: WB Saunders.

28. Trinder, $P$. (1951). Cited in Biosystem Kits for determination of sodium concentration. Analyst, 76: 596.

29. Eden, A., and Green, H.H., (1940). Cited in Biosystem Kits for determination of potassium concentration, Biochem. J. 34, 1202.

30. SchÖnfeld, R.G., and Lowellen, C.S., (1964). Cited in Biosystem Kits for determination of chloride concentration, Clin. Chim, 10, 533.

31. Aebi, H. (1984). Methods enzymol 105: 121 -126.

32. Moron, M. S.; Depierre, J. W. and Mannervik, B. (1979). Levels of glutathione, glutathione reductase and glutathione S-transferase activities in rat lung and liver. 
Biochimica et Biophysica ACTA 582, 67-78.

33. Montgomery, H.A.C., and Dymock, J.F., (1961). Colorimetric determination of nitrite. Analyst, 86,414.

34. Bancroft, J.D., and Gamble, M., (2008). Theory and Practiceof Histological Techniques. 6th ed., (Churchill Livingstone, Elsevier, Philadelphia).

35. Adel, M., Alousi, L.A, Salem, H.A. (2005): Licorice: A possible anti-inflammatory and anti-ulcer drug. AAPS Pharm. Sci. Tech. 6: 74-82.

36. Biplab, A., Sudhir, K.Y., Kshama, R., Sandip, K.B., Subrata, C., (2011). Black tea and the aflavins assist healing of indomethacin-induced gastric ulceration in mice by antioxidative action, Evid Based Complem Alt Med. (11): 11-22.

\section{Muhammed}

A.V.K., Thamotharan G., Sengottuvelu S., Haja-Sherief S., Sivakumar T., (2012). Evaluation of antiulcer activity of Ficuspumila L. leafextract in albino rats, Glob J Res Med Plants Indig Med; 1(8): 340351.

38. Grossman, M.I. (1978). Control of gastric secretion in gastrointestinal disease, Patho physiology- diagnosis and management. Sleisenzer, M.H, Fordtran, J.S., editors. 2nd ed. W B Saunders Co, Philadelphia, p.640- 659.
39. Miller, T. (1983). Protective effects of prostaglandins against gastric mucosal damage: current knowledge and proposed mechanisms. Am. J. Physiol., 235:G601-G623.

40. Lüllmann, H., Mohr, K., Ziegler, A., Bieger, D., (2000). Color atlas of pharmacol-ogy, 2nd ed., Thieme Stuttgart, New York, pp. 166.

41. Yoshikawa T, Naito $Y$, Kishi A, Tomii T, Kaneko T, Iinuma S, Ichikawa $\mathbf{H}$, Yasuda M, Takahashi S, Kondo M. (1993). Role of active oxygen, lipid peroxidation, and antioxidants in the pathogenesis of gastric mucosal injury induced by indomethacin in rats.34: $732-$ 741

42. Halici M., F. Odabasoglu, H. Suleyman, A. Cakir, A. Aslam, Y. Bayir, (2005). Effect of water extract of Usnealongissima on antioxidant enzymeactivity and mucosal damage caused by indomethacin in rats, Phytomedicine; (12): 656-662.

43. Khare, C.P. (2004). Encyclopedia of Indian Medicinal Plants. New York: Springer-Verlag; 233-235.

44. Alkofahi, A. and Atta, A. (1999). Pharmacological screening of the antiulcerogenic effects of some Jordanian plants in rats. J. Ethnopharmacol., 67(3): 341345. 
45. Khayyal, M.; El Ghazaly, A.; Kenaway, S.; Seif El Nasr, M.; Mahran, L.; Kafafi, Y. and Okpanyi, S. (2001). Antiulcerogenic effect of some gastro-intestinally acting plant extracts and their combinations. Arzneimittel Forschung, 51: 545-553.

46. Ji-Yeon Yu, Jae Yeo Ha, Kyung-Mi Kim, Young-Suk Jung, Jae-Chul Jung, and Seikwan Oh, (2015). AntiInflammatory Activities of Licorice Extract and Its Active Compounds, Glycyrrhizic Acid, Liquiritin and Liquiritigenin, in BV2 Cells and Mice Liver, Molecules, 20, 13041-13054; doi:10.3390/molecules2007130 41.

47. Hodek P, Trefil P, and Stiborová M. (2002). Flavonoids-potent and versatile biologically active compounds interacting with cytochromes P450. Chem. Biol. Interact. 139:1-21.

48. Falzon, M., Whiting, PH, Ewen, SW, Milton, A.S and Burke MD (1985). Comparative effects of indomethacin on hepatic enzymes and histology and on serum indices of liver and kidney function in the rat. $\mathrm{Br} \mathrm{J}$ Exp Pathol. 66(5): 527-534.

49. Tarek Rahmy, Abeer Alahmari, Faiza Abdu and Osama Abu-Zinadah (2013). protective effect of melittin against gastric inflammation in mice. Life SCi. J. ; 10 (2): 1369-1384.

50. Klaassen, C. D. (2001) Casarett and Doull $=\mathrm{s}$ Toxicology: the Basic Science of Poison. 6th Eds The McGrau-Hill Companies Inc. New York.

51. Bush, B. M. (1991). Interpretation of Laboratory results for small animal clinicians. Blackwell Scientific Publications London.

52. Eisenburg, J. (1992). Treatment of chronic hepatitis B. part 2: Effect of glycyrrhizinic acid on the course of illness. Forschr. Med., 110: 395-398.

53. Tamir, S.; Eisenburg, J.; Somjen, D. and Izrael, S. (2000). Natural compounds for medicinal use. J. Steroid. Biochem. Mol. Biol., 78: 291298.

54. Deng, Y.; Wu, K.; Wan, J.; Li, L.; Jiang, R.; Jia, M.; Jing, Y.; Zhang, L. (2012). Aminotriazole attenuated carbon tetrachloride-induced oxidative liver injury in mice. Food Chem. Toxicol. 50, 30733078.

55. Upur, H.; Amat, N.; Blazekovic, B.; Talip, A. (2009). Protective effect of Cichorium glandulosum root extract on carbon tetrachlorideinduced and galactosamineinduced hepatotoxicity in mice. Food Chem. Toxicol., 47, 2022-2030. 
56. Wolf, P.L.; Williams, D.; Tsudaka, T. and Acosta, L. (1972). Methods and Techniques in Clinical Chemistry. Wiley-Interscience adivison of John Wiley and Sons, Idnc., New York, London, Sydney, Toronto.

57. Hemieda FA, Elmissiry MA, Badawy M.E, Goda AA (2004). Partial suppressive effect of melatonin on indomethacin-induced renal injury in rat. Indian J. Exp. Biol., 42, 63-67

58. Polat B, Suleyman H, Alp HH (2010). Adaptation of rat gastric tissue against indomethacin toxicity. Chem. Biol. Interact., 7:186(1): 82-89.

59. Yokozawa, T.; Lin, Z. and Chen, C. (2000). Protective effect of Glycyrrhiza glabra in renal hypoxy-reoxygenation model. Phytomed., 6: 439-445.
60. Kumar, T.; Stanley, V.; Lal, A. and Bala, S.M. (2002). Biochemical evaluation of multiple herbal treatment in alloxan-diabetic rats. J. Environ. Biol., 23: 407-410.

Table 1: Effect of licorice and ranitidine pretreatment on volume, pH, and Total Acidity on rat with induced gastric ulcer

\begin{tabular}{|c|c|c|c|}
\hline \multirow[b]{2}{*}{ Group } & \multicolumn{3}{|l|}{ Parameter } \\
\hline & Volume (ml) & $\mathrm{pH}$ & $\begin{array}{l}\text { Total Acidity } \\
(\mathrm{mEq} / \mathrm{L} / 100 \mathrm{~g})\end{array}$ \\
\hline Group I & $1.70 \pm 0.08^{\mathrm{c}}$ & $4.82 \pm 0.06^{\mathrm{ab}}$ & $36.5 \pm 2.69^{b c}$ \\
\hline Group II & $1.44 \pm 0.04^{\mathrm{d}}$ & $5.01 \pm 0.07^{\mathrm{a}}$ & $32.1 \pm 2.40^{c}$ \\
\hline Group III & $2.79 \pm 0.11^{\mathrm{a}}$ & $3.76 \pm 0.13^{\mathrm{c}}$ & $56.5 \pm 3.66^{\mathrm{a}}$ \\
\hline Group IV & $1.99 \pm 0.08^{\mathrm{b}}(45.6 \%)^{@}$ & $4.52 \pm 0.09^{b}$ & $41.0 \pm 2.80^{\mathrm{b}}$ \\
\hline Group V & $1.97 \pm 0.08^{\mathrm{b}}(48.6 \%)^{@}$ & $4.63 \pm 0.14^{\mathrm{b}}$ & $41.8 \pm 2.34^{\mathrm{b}}$ \\
\hline
\end{tabular}

Values are means \pm standard errors. Means without a common superscript in a column differ significantly $(\mathrm{P} \leq 0.05)$. @ Decrease ratio in gastric volume relative to Indomethacin group. Group I: control, Group II: licorice, Group III: indomethacin, Group IV:

licorice/indomethacin, Group V: ranitidine/ indomethacin. 
Table 2: Effect of licorice and ranitidine pretreatment on Ulcer score, Ulcer index, and IL6 on rat with induced gastric ulcer

\begin{tabular}{|c|c|c|c|}
\hline \multirow[b]{2}{*}{ Group } & \multicolumn{3}{|l|}{ Parameter } \\
\hline & Ulcer score* & Ulcer index & IL-6 (pg/ml) \\
\hline Group I & $0(0,0)^{\mathrm{c}}$ & $0.00 \pm 0.00^{c}$ & $2.31 \pm 0.04^{\mathrm{c}}$ \\
\hline Group II & $0(0,0)^{\mathrm{c}}$ & $0.00 \pm 0.00^{c}$ & $2.11 \pm 0.09^{c}$ \\
\hline Group III & $3(1,4)^{\mathrm{a}}$ & $4.26 \pm 0.96^{\mathrm{a}}$ & $10.9 \pm 1.18^{\mathrm{a}}$ \\
\hline Group IV & $2(0,3)^{\mathrm{ab}}$ & $2.34 \pm 0.52^{\mathrm{b}}(-45.1 \%)^{@}$ & $6.56 \pm 0.19^{b}$ \\
\hline Group V & $1(0,3)^{b}$ & $2.27 \pm 0.48^{\mathrm{b}}(-46.7 \%)^{@}$ & $7.92 \pm 0.24^{\mathrm{b}}$ \\
\hline
\end{tabular}

Table 3: Effect of licorice and ranitidine pretreatment on CAT, GSH, NO and MDA on rat with induced gastric ulcer

\begin{tabular}{lllll}
\hline & Parameter & & \\
\cline { 2 - 5 } Group & $\begin{array}{l}\text { Catalase } \\
\text { (unit/g tissue) }\end{array}$ & $\begin{array}{l}\text { Reduced } \\
\text { glutathione } \\
(\mathrm{mg} / \mathrm{g} \text { tissue })\end{array}$ & $\begin{array}{l}\text { Nitric oxide } \\
(\mu \mathrm{mol} / \mathrm{g} \text { tissue })\end{array}$ & $\begin{array}{l}\text { Malondialdehyde } \\
(\mu \mathrm{mol} / \mathrm{g} \text { tissue })\end{array}$ \\
\hline Group I & $0.74 \pm 0.11^{\mathrm{ab}}$ & $21.6 \pm 2.31^{\mathrm{ab}}$ & $9.20 \pm 0.21^{\mathrm{ab}}$ & $6.48 \pm 0.24^{\mathrm{d}}$ \\
Group II & $0.88 \pm 0.04^{\mathrm{a}}$ & $25.2 \pm 1.79^{\mathrm{a}}$ & $9.83 \pm 0.27^{\mathrm{a}}$ & $6.00 \pm 0.26^{\mathrm{d}}$ \\
Group III & $0.38 \pm 0.03^{\mathrm{d}}$ & $8.29 \pm 0.48^{\mathrm{d}}$ & $7.39 \pm 0.28^{\mathrm{c}}$ & $19.2 \pm 0.20^{\mathrm{a}}$ \\
Group IV & $0.58 \pm 0.05^{\mathrm{bc}}$ & $16.2 \pm 0.52^{\mathrm{c}}$ & $8.53 \pm 0.31^{\mathrm{b}}$ & $11.1 \pm 0.52^{\mathrm{c}}$ \\
Group V & $0.47 \pm 0.04^{\mathrm{cd}}$ & $18.5 \pm 0.47^{\mathrm{bc}}$ & $8.24 \pm 0.30^{\mathrm{bc}}$ & $14.0 \pm 0.67^{\mathrm{b}}$
\end{tabular}

Values are means \pm standard errors. Means without a common superscript in a column differ significantly $(\mathrm{P} \leq 0.05)$. Group I: control, Group II: licorice, Group III: indomethacin, Group IV: licorice/indomethacin, Group V: ranitidine/ indomethacin. 
Table 4: Effect of licorice and ranitidine pretreatment on Total protein, Albumin, Globulin and $\mathrm{A} / \mathrm{G}$ ratio on rat with induced gastric ulcer

\begin{tabular}{|c|c|c|c|c|}
\hline \multirow[b]{2}{*}{ Group } & \multicolumn{4}{|l|}{ Parameter } \\
\hline & $\begin{array}{l}\text { Total protein } \\
(\mathrm{g} / \mathrm{dl})\end{array}$ & Albumin $(\mathrm{g} / \mathrm{dl})$ & Globulin (g/dl) & $\begin{array}{l}\text { Albumin to } \\
\text { globulin } \\
\text { ratio }\end{array}$ \\
\hline Group I & $5.16 \pm 0.10^{\mathrm{a}}$ & $4.32 \pm 0.06^{\mathrm{a}}$ & $0.85 \pm 0.09^{\mathrm{a}}$ & $5.56 \pm 0.52^{c}$ \\
\hline Group II & $4.71 \pm 0.12^{b}$ & $4.11 \pm 0.13^{\mathrm{ab}}$ & $0.60 \pm 0.05^{\mathrm{b}}$ & $7.28 \pm 0.57^{\mathrm{ab}}$ \\
\hline Group III & $3.81 \pm 0.07^{\mathrm{c}}$ & $3.39 \pm 0.06^{\mathrm{c}}$ & $0.42 \pm 0.01^{\mathrm{c}}$ & $8.17 \pm 0.30^{\mathrm{a}}$ \\
\hline Group IV & $4.42 \pm 0.17^{\mathrm{b}}$ & $3.78 \pm 0.17^{b c}$ & $0.64 \pm 0.04^{\mathrm{b}}$ & $6.12 \pm 0.44^{b c}$ \\
\hline Group V & $4.02 \pm 0.16^{\mathrm{c}}$ & $3.49 \pm 0.16^{\mathrm{c}}$ & $0.52 \pm 0.04^{\mathrm{bc}}$ & $7.14 \pm 0.70^{\mathrm{ab}}$ \\
\hline
\end{tabular}

Table 5: Effect of licorice and ranitidine pretreatment on liver function (AST, ALT) on rat with induced gastric ulcer

\begin{tabular}{lll}
\hline & \multicolumn{2}{l}{ Parameter } \\
\cline { 2 - 3 } $\begin{array}{l}\text { Alanine } \\
\text { aminotransferase } \\
\text { Group }\end{array}$ & $\begin{array}{l}\text { Aspartate } \\
\text { aminotransferase } \\
(\mathrm{U} / \mathrm{L})\end{array}$ \\
\hline Group I & $31.1 \pm 1.19^{\mathrm{b}}$ & $173 \pm 2.52^{\mathrm{ab}}$ \\
Group II & $51.1 \pm 2.41^{\mathrm{a}}$ & $162 \pm 11.9^{\mathrm{b}}$ \\
Group III & $44.6 \pm 2.16^{\mathrm{b}}$ & $190 \pm 7.68^{\mathrm{a}}$ \\
Group IV & $51.1 \pm 1.70^{\mathrm{a}}$ & $177 \pm 6.82^{\mathrm{ab}}$ \\
Group V & & $190 \pm 4.02^{\mathrm{a}}$ \\
\hline alues are means \pm standard errors. Means without a common superscript in a column differ \\
gnificantly (P $\leq 0.05)$. Group I: control, Group II: licorice, Group III: indomethacin, Group
\end{tabular}


Table 6: Effect of licorice and ranitidine pretreatment on kidney function (Urea, Uric acid) on rat with induced gastric ulcer

\begin{tabular}{lll}
\hline & \multicolumn{2}{l}{ Parameter } \\
\cline { 2 - 3 } Group & Urea $(\mathrm{mg} / \mathrm{dl})$ & Uric acid $(\mathrm{mg} / \mathrm{dl})$ \\
\hline Group I & $47.5 \pm 1.64^{\mathrm{a}}$ & $5.10 \pm 0.13^{\mathrm{bc}}$ \\
Group II & $42.0 \pm 1.15^{\mathrm{b}}$ & $4.82 \pm 0.13^{\mathrm{c}}$ \\
Group III & $50.0 \pm 1.09^{\mathrm{a}}$ & $5.62 \pm 0.21^{\mathrm{a}}$ \\
Group IV & $48.0 \pm 2.23^{\mathrm{a}}$ & $5.27 \pm 0.11^{\mathrm{abc}}$ \\
Group V & $50.0 \pm 1.32^{\mathrm{a}}$ & $5.47 \pm 0.20^{\mathrm{ab}}$
\end{tabular}

Values are means \pm standard errors. Means without a common superscript in a column differ significantly $(\mathrm{P} \leq 0.05)$. Group I: control, Group II: licorice, Group III: indomethacin, Group IV: licorice/indomethacin, Group V: ranitidine/ indomethacin.

Table 7: Effect of licorice and ranitidine pretreatment on minerals ( $\mathrm{Na}, \mathrm{K}$, and $\mathrm{Cl}$ ) on rat with induced gastric ulcer

\begin{tabular}{llll}
\hline & \multicolumn{2}{l}{ Parameter } & \\
\cline { 2 - 4 } Group & Sodium $(\mathrm{mmol} / \mathrm{l})$ & $\begin{array}{l}\text { Potassium } \\
(\mathrm{mmol} / \mathrm{l})\end{array}$ & Chloride $(\mathrm{mmol} / \mathrm{l})$ \\
\hline Group I & $145 \pm 0.30^{\mathrm{a}}$ & $5.84 \pm 0.21^{\mathrm{a}}$ & $98.6 \pm 0.54^{\mathrm{a}}$ \\
Group II & $143 \pm 0.70^{\mathrm{a}}$ & $5.40 \pm 0.15^{\mathrm{ab}}$ & $99.2 \pm 0.61^{\mathrm{a}}$ \\
Group III & $144 \pm 0.29^{\mathrm{a}}$ & $5.44 \pm 0.16^{\mathrm{ab}}$ & $101 \pm 0.37^{\mathrm{a}}$ \\
Group IV & $142 \pm 1.38^{\mathrm{a}}$ & $5.18 \pm 0.14^{\mathrm{b}}$ & $101 \pm 1.15^{\mathrm{a}}$ \\
Group V & $143 \pm 1.31^{\mathrm{a}}$ & $5.48 \pm 0.09^{\mathrm{ab}}$ & $101 \pm 0.93^{\mathrm{a}}$ \\
\hline
\end{tabular}

Values are means \pm standard errors. Means without a common superscript in a column differ significantly $(\mathrm{P} \leq 0.05)$. Group I: control, Group II: licorice, Group III: indomethacin, Group IV: licorice/indomethacin, Group V: ranitidine/ indomethacin 


\section{Morphological investigation (PM)}

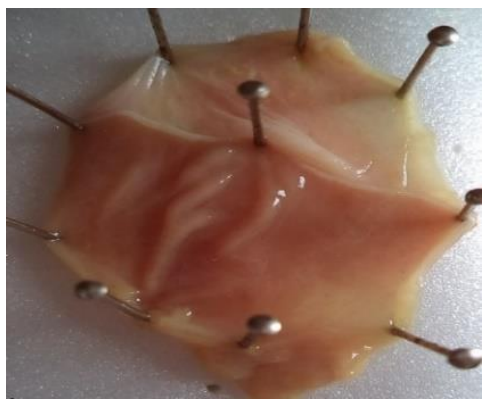

Fig. 1 A control

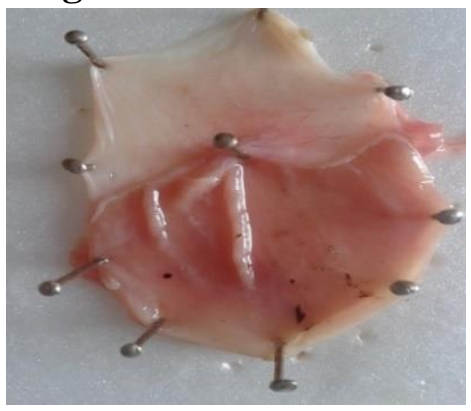

Fig. 1 D licorice/INDO

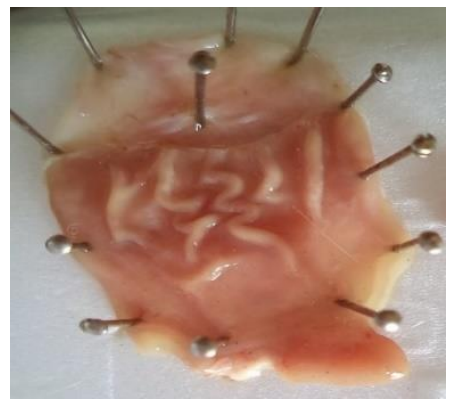

Fig. 1 B licorice

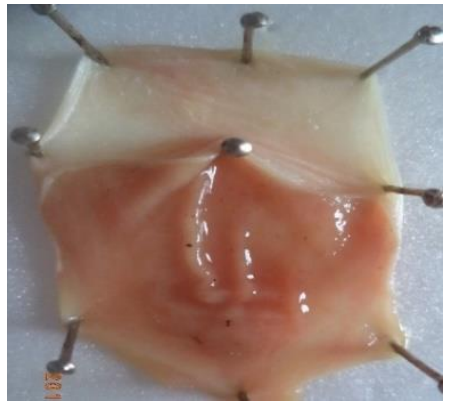

Fig. 1 E Ranitidine /INDO

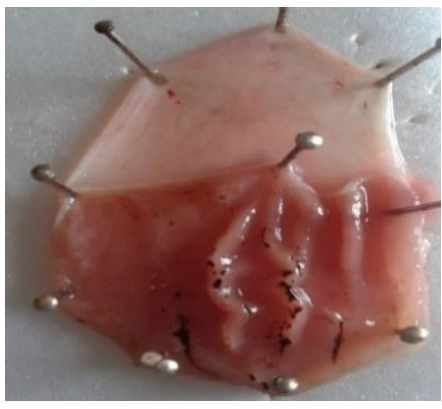

Fig. $1 \mathrm{C}$ indomethacin

Fig. 1A \& Fig. 1B; showed normal gastric mucosa, epithelial cells, with no evident of inflammation. Fig. 1C showed; marked gross mucosal lesions, including long hemorrhagic bands of different sizes and petechial lesions with ulcerative inflammation. Fig. 1D \& Fig. 1E showed; successful reduced ulcer with very mild mucosal lesions.

\section{Histopathological investigation:}

The histopathological findings confirmed the protective effects of licorice that showed preservation of the normal tubular arrangement of gastric glands. Minor changes in the structure of gastric glands in form of widening of the pits with no visible ulceration.

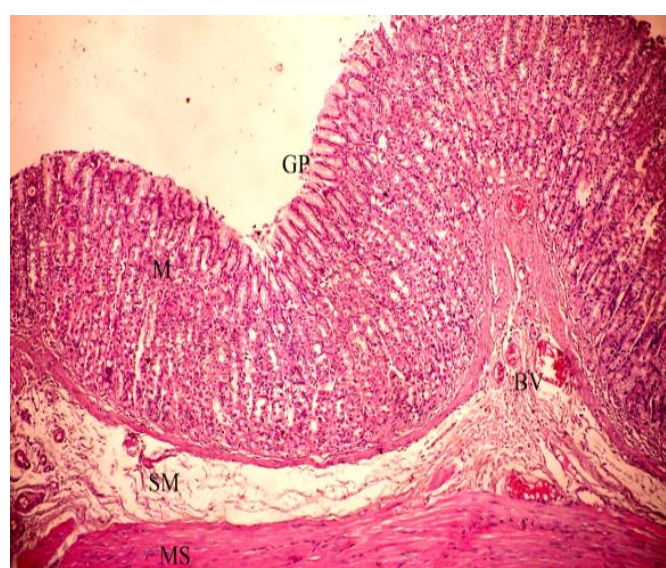

Fig. 2 A control

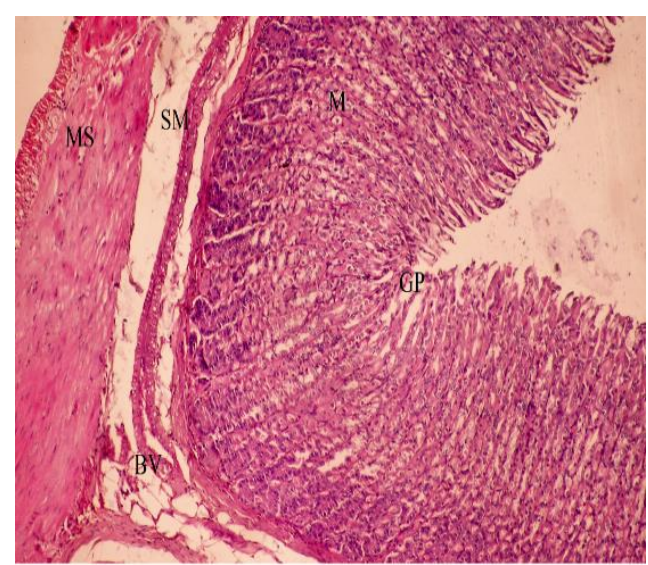

Fig. 2B licorice 


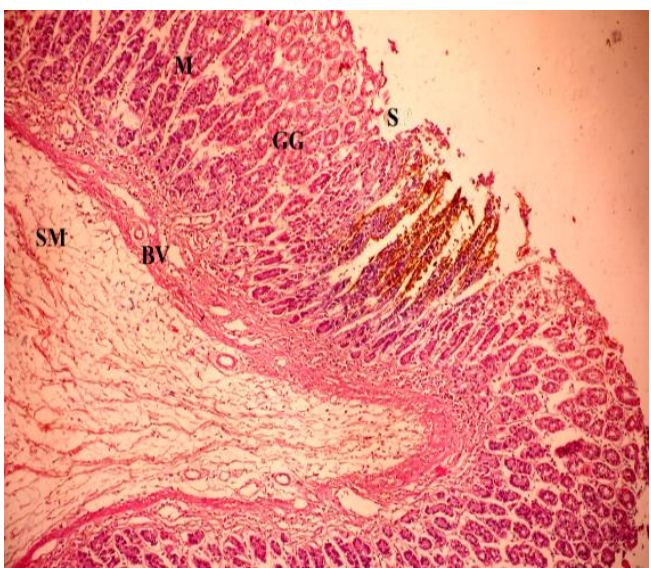

Fig. 2C indomethacin

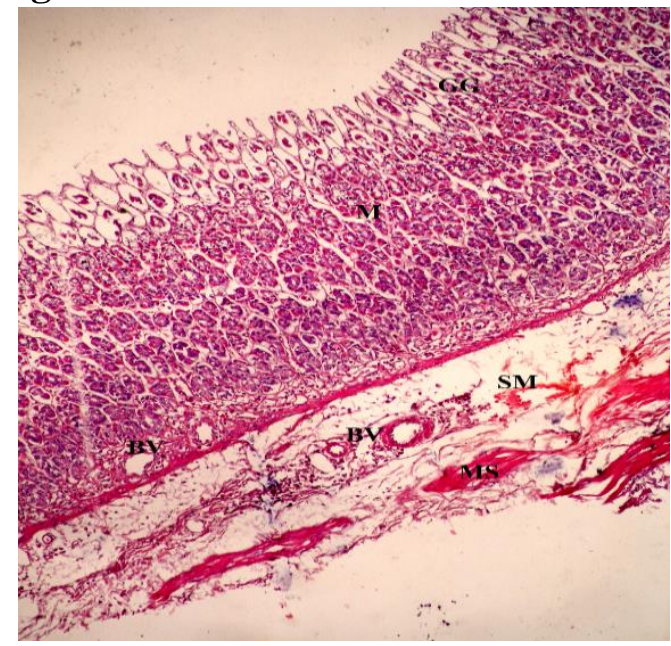

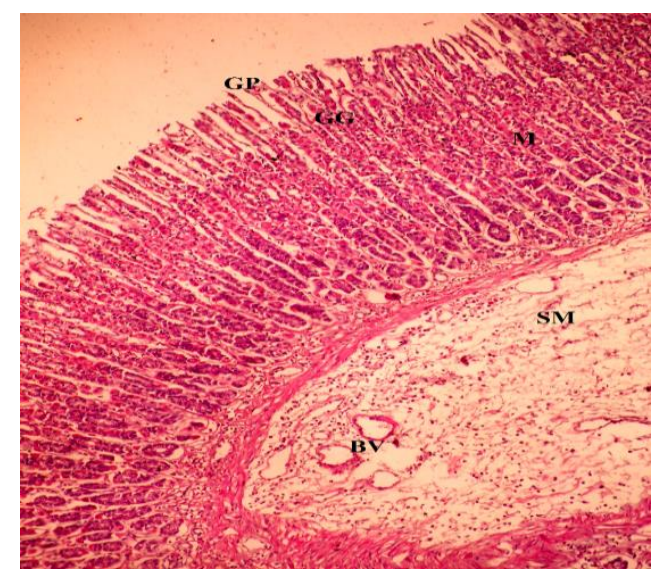

Fig. 2D licorice/ indomethacin

Fig. 2E ranitidine/indomethacin

Figure 2: Histological architecture of rat stomach tissue (A) showed; intact smooth surface epithelium interrupted by openings of the gastric pit (GP). Normal gastric mucosa (M). Muscularis mucosa (MS) well differentiated at the basement membrane; normal blood vessels (BV). (B) showed; intact surface epithelium with mild dilated gastric pits (GP), Normal muscularis (MS), Normal blood vessels (BV). (C) showed; sever distraction of surface epithelium and sloughing (S) with sever dilated gastric pits (GP), sever destructive muscularis (MS), invasion of mucosa by numerous hemorrhaged blood vessels (BV). Marked edema and congestion in sub mucosa. (D) showed; moderate disruption of the surface epithelium, dilated gastric pit (GP), preservation of normal tubular arrangement of gastric glands (GG), dilated blood vessels (BV), and extensive edema of the submucosal layer. (E) showed; sever disruption of the surface epithelium. There was edema and distraction of the gastric pit (GP), marked dilation and hemorrhaged blood vessels (BV) invasive to muscularis mucosa as the increased of partial cells in mid and basal of gastric gland (H\&E stains 10Xmagn). 